\title{
The Most Effective Approaches to Increasing Parental Involvement
}

\author{
Erin K. Butler \\ Jacksonville State University \\ Carol Uline \\ Jacksonville State University \\ Charles E. Notar (Corresponding author) \\ College of Education and Professional Studies, Jacksonville State University \\ 700 Pelham Road North \\ Romona Wood A3 \\ Jacksonville, Alabama 36265, USA \\ Tel: 1-256-782-5832Ｅ-mail: cnotar@jsu.edu
}

\begin{abstract}
The paper is by a first year master's student in the introductory educational research class. Her problem was "What is the most effective approach to increasing parental involvement with positive student achievement outcomes in grades K-8 She found educators must use a variety of methods to obtain and sustain parental involvement. Schools must be proactive by explicitly inviting parents to be their partners Interactive homework (student notebooks, checklists, quick notes, and reminders) has powerful potential for promoting family-school partnerships which increase constructive learning outcomes. Using technology can help make home-school links more effective. When parents and the educational system join together, positive benefits abound. Attendance, test scores, and high-school graduation rates improve. Teachers have higher expectations for parents and students and they develop more positive feelings about teaching. Extensive parental involvement promotes healthy neighborhoods and good schools.
\end{abstract}

Keywords: Parental Involvement, Positive Student Outcomes, Family-School Partnership, Parent-Teacher Relationships, Parent-Teacher Cooperation

\section{Introduction}

Across the nation, school systems recognize the need to engage families and communities as active partners in the shared responsibility for educating young people. With much national concern and debate over the No Child Left Behind Act, accountability drives administrators and teachers to investigate more effective approaches to collaborate with parents for increasing student learning.

Many researchers have investigated the impact that parental support in school activities has on students. Parental involvement positively affects student achievement outcomes. Children who enjoy support of their parents exhibit more positive attitudes and higher academic achievement than children who do not enjoy consistent parental interest and help with their school activities. Children who receive the same education as their peers, but who do not get support at home, do not perform as well in class or on standardized tests as children who enjoy the benefits of "involved" parents. An old adage states: "It takes a village to raise a child." Children benefit significantly when adults take a strong interest in their education; plus, the entire community benefits proportionately.

Parental involvement in early education (K-3) is easier to solicit than in the later elementary years when parental interest tends to diminish. The change to poorer grades and negative attitudes toward school as a child gets older, may in part, be due to the waning interest of parents. Perhaps if parents were provided with knowledge of the importance of continued parental involvement and were reinforced with some strategies for maintaining parental involvement throughout their children's formal education, both students and parents would benefit from the collaborative experience.

\section{Related Literature}

One way for parents to maintain involvement with their children's school activities is to supervise and help with homework. Parents who monitor and assist with homework, limit TV viewing, and read to young children set the stage for higher long-term student achievement. Hoover-Dempsey, Battiato, Walker, Reed, DeJong, and Jones (2001) 
found that parents who regularly help their children with their homework model higher expectations for their children's academic achievement. In addition to such modeling, children profit from parental reinforcement and parental feedback about their academic performance. The authors stress the importance for principals and teachers to explicitly and specifically invite parents to show interest and to offer guidance in their children's homework activity.

Schools may take specific steps to enhance parental involvement motivations. For example, they may communicate directly and specifically why and how it is important to children's learning. They may offer other specific suggestions that they do indeed have a role to play in their children's success and that their activities make a difference (Hoover-Dempsey, Battiato, Walker, Reed, DeJong, and Jones, 2001).

The authors of the study used data from a variety of action-research projects. The literature base includes studies incorporating explicit attention to parents' involvement with homework as well as related sources helpful in understanding parents' involvement decisions, the content of their involvement and its outcomes. The research indicates that parents involve themselves in their children's homework for a number of reasons. These parents believe that they should be involved; they believe that their involvement will make a positive difference; and they perceive school invitations for involvement. Parents who provide positive feedback and encouragement influence their children's self perceptions and build their self confidence. Parents provide reinforcement and they engage in instructional interactions related not only to the homework but also to the entire learning process.

Walker, Hoover-Dempsey, Reed, and Jones, (2000) examined the links between children's invitations for help with homework and parents' levels of involvement in children's homework activities. This study is grounded in Hoover-Dempsey and Sandler's model of the parent involvement process (Appendix A). The authors concluded that there were four child attributes in inviting parents to become involved with their child's homework. The four attributes include (1) the child's general level of performance, (2) the child's experience of difficulty with daily homework, (3) the child's developing desire for independence, and (4) the child's valuing of the parents' involvement activities.

Twenty public school fourth graders and their parents (one per child) individually responded to questionnaires. Two questionnaires were designed for this study. Thinking About My Homework (TAMH) was a questionnaire designed for children. Thinking About My Child's Homework (TAMCH) was a questionnaire designed for the parents. Items for both questionnaires were derived from the Hoover-Dempsey and Sadler (1995) study.

The results suggested that parents were motivated to help with homework when their child was getting lower grades or if their child experienced difficulty with his/her school work. The data collected suggests that a child's invitations may or may not be as powerful as other theorized contributors to parental involvement. These contributors include the following.

(1) Parents perceive their parental role as participating in their children's education.

(2) Parents have a positive sense of efficacy for helping their children to succeed in school.

(3) Parents receive opportunities or invitations for involvement from their children or from the school. (Hoover-Dempsey et al., 1995)

The authors found that based on self-efficacy and desire for involvement, the parents' degree of involvement seemed to be a mix a conviction that they can make a positive impact on their child's learning, employment demands and other family responsibilities, as well as specific invitations by the child or the child's school. Using the reasons for why parents become involved, the authors created a model of how such involvement positively influences student achievement. The mechanisms of influence are modeling, reinforcement, and direct instruction. Modeling allows parents to influence their child's educational outcomes by demonstrating that activities related to school are worthy of adult interest. Most children desire to emulate their parents. Reinforcement is effective because children often desire to please their parents. Parents who place an importance on school-related activities, such as studying for tests, completing homework, and asking the teacher questions, impress on the child the value of these academically-oriented behaviors.

Direct instruction comes in two primary forms, which generally yield different learning outcomes for children. Parents who engage in direct, closed-ended instruction (giving orders, commands, and requests for correct answers) tend to promote factual learning and knowledge but do not promote higher-order thinking skills. Parents who engage in direct, open-ended instruction (asking questions, requesting plans, and explaining concepts) tend to promote factual knowledge as well as a higher level of cognitive thinking (Hoover-Dempsey and Sadler, 1995). The complete model is listed in Appendix A.

Hoover-Dempsey et al. (1995) suggest that their model identifies parental involvement as a process which is dynamic and occurs over time. Parental, school, child, and societal contributions, taken together, constitute the involvement process. Parents in low socioeconomic environments, who struggle to meet basic survival needs for their families, may 
not fit the model presented in Appendix A. Poor parents are less likely to get involved in school activities, not only because of the hardship of survival but also because of a sense of intimidation and past negative school experiences.

Other researchers have explored the problem of how to get parents involved with the school life of their children. Patterson (1994) wrote a dissertation describing a program that was implemented in a rural elementary school in Florida. The school's goal was to increase parental involvement of students in grades one, four, and five. The characteristics of the students in this study were African American, came from single-parent households, and were considered low-income. A pre-program survey revealed that many parents reported involvement in such activities as reading to their children, assisting with homework, and discussing school with their children. Parent workshops were conducted and handbooks were distributed. The program centered on workshops held over a three-month period to teach parents techniques for helping their children with homework assignments. Homework activities requiring parental participation were sent home to bridge the gap for parents who were unable to attend the workshops.

Program evaluation revealed that although the workshops, handbooks, and interactive homework activities served to increase some parental involvement, the increase was not significant. Parents rated the program as beneficial; however, parental participation was not consistent. Many parents found that trying to balance a head-of-household status, along with attending workshops, became laborious and almost impossible. The author concluded that although single parents in low socioeconomic areas have the desire to become involved with their children's school work, lack of time prevents such busy parents from doing so over an extended period (Patterson, 1994).

Bal and Goc (1999) sought ways to increase parental involvement to improve academic achievement in the subjects of reading and math for fourth-through-sixth-grade students in two Midwestern metropolitan schools. This action-research project included thirty-four students. Four types of interventions were attempted: "Using a variety of communication tools to enforce two-way communication; providing information about how parents can assist learning at home; regularly assigning interactive homework that required interaction with parents; and distributing student work for parental comment and review on a regular basis"(Bal et al., 1999). Pre-and-post intervention surveys were administered to both students and parents. The surveys attempted to ascertain communication frequency and parental academic involvement with their children. Reading and math tests were used to measure academic improvement of the students. Teachers were asked to use the telephone to inform parents of positive and negative concerns on a regular basis. In addition, weekly teacher checklists were devised to inform the parents of work completion and grades earned. Each student was given a notebook to record homework. The notebooks provided space for teacher and/or parent comments. Parents were asked to view the notebook daily and to verify the completion and accuracy of the assigned work before signing it. Parents were also provided with information regarding how they could assist learning at home. A program orientation was conducted at open house; monthly newsletters were sent home; and guides in assisting particular academic skills were offered.

Post-intervention data indicated a modest increase in parental involvement. The data indicated a slight improvement in reading, but no improvement in math performance. (Pre-and-post survey questions are in Appendix C. Survey results are displayed in Appendix B.)

Salend, Duhaney, Anderson, and Gottschalk (2004) provide guidelines and examples for using the Internet as an interactive tool for facilitating comprehensive two-way communication between teachers and parents regarding homework. The homework assignments used in this article were designed to provide students with additional instructional time to master the general education curriculum and to share information with families regarding their children's progress. The authors developed a three-phase system for a Homework Assistance Center (HAC). A Homework Assistance Center website was introduced gradually so that parents and students could slowly acclimate themselves to the system. Phase 1 of HAC consists of seven sections. "Section 1 is a welcome paragraph that provides parents with an overview of the site. Section 2 contains website guidelines. Section 3 displays an index. Section 4 lists frequently-asked questions with answers. Section 5 delineates the homework policy. Section 6 contains homework-assistance recommendation. Section 7 provides teacher contact information.

Phase 2 has three sections (1) homework assignments, (2) homework models and rubrics, (3) homework and curriculum standards connection. Finally, phase 3 has six sections (1) online homework resources, (2) digital dropbox, (3) online homework groups, (4) web-based information evaluation guidelines, (5) online survey of website, and (6) digital suggestion box (Salend et al., 2004).

Salend et al. (2004) found that a homework website is a very effective method of involving parents in student homework. The current generation of children grow up with fast and efficient computers. Using the Internet to complete homework provides an exciting learning activity which allows children to learn without realizing they are working. Parents are more inclined to assist children with Internet homework because it is convenient, immediate, and efficient. Teachers also benefit from the homework website. On the web, the teacher can more easily adapt homework to the educational needs of individual students. Varying content, length, and purpose of the assignment as well as modifying response modes, extending timelines, and employing alternative evaluation strategies are some of the many 
decision-making responsibilities of the teacher which can be carried out much more efficiently with the use of the Internet. Turning in homework digitally, helps eliminate problems that some students have with turning in homework on time or turning it in at all.

Tobolka (2006) also conducted a research project using the Internet to enhance parental involvement. As an elementary school teacher, Tobolka created a user-friendly website combined with e-mail to communicate with parents. The author used both qualitative and quantitative data during a six-week project. Prior to the study, the author held a tutorial in the computer lab so that parents could learn how to easily access the website and e-mail messages. The data collected were from parent surveys, student interviews, e-mails, checklists, and observations. Both before-and-after surveys were posted on the website for parents. Student interviews were conducted on an individual basis to determine student use of the website at home and at school. Students were asked if they would like their parents to become more involved in their school activities. At the end of each week, the author sent e-mails to parents about student behavior, missing work, as well as quick notes and reminders. Checklists and observations were used to keep track of student improvement.

The results of Tobolka's action research suggested that electronic communication improves students' interest in their schoolwork and provides parents with more knowledge about daily class activities. Parents felt more involved in their children's school activities and they felt more connected with the teacher. Students felt that it was important to work hard on class work and to turn in homework so that they could get a positive electronic note home at the end of the week.

An experimental study in the content area of science was conducted by Van Voorhis (2003). He examined the effects of weekly interactive science homework on family involvement in homework, student achievement, and homework attitudes. The experimental study was conducted with sixth-and-eighth-grade students at Clearwater Middle School in a Mid-Atlantic state. Sixth grade and eighth grade science teachers participated in the study which included 253 students over a period of 18 weeks. The teachers conducted homework interaction over the first two marking periods.

Six classes completed Teachers Involve Parents in Schoolwork (TIPS) with directions for parent and family involvement. Examples of TIPS assignment topics include: "Student conducts a simple home experiment by using liquids of different thicknesses, and then discusses the results with a family member. Student asks family members for their shoe sizes or heights and then computes the averages. Student interviews a family member about hairstyles that were popular when he/she was the student's age, then writes a paragraph about those hairstyles, and reads the paragraph aloud to a family member"(Van Voorhis, 2003). Four classes completed non-interactive homework.

Interactive students reported significantly higher levels of family involvement than did non-interactive students. Students in both groups who had more regularly-involved family members completed more assignments. More TIPS students turned in accurate assignments than did non-TIPS students. TIPS students also earned significantly higher science report-card grades. Higher levels of family involvement in TIPS science did not carry over to other subject areas such as language arts and mathematics classes which did not include the TIPS design. The findings of the experimental study support the hypothesis that TIPS interactive homework affects family involvement in homework, science attitudes, and student achievement in the middle grades.

Bailey, Silvern, Brabham, and Ross (2004) attempted to determine if designing interactive reading homework would increase parental involvement and improve students' abilities to draw inferences from reading.

The subjects in this interactive-homework study were second graders pulled from three schools in the Southeastern Alabama. The students were separated into two experimental groups and one control group. Of the three schools, School One was under warning of takeover by the State Department of Education; School Two received a "C+" on the State Department of Education Report Card, and School Three held an academic status of "B+" on the State Department of Education Report Card. One hundred percent of the students at School One qualified for free or reduced lunch. Sixty-five percent of School Two's students qualified for free or reduced lunch, and 75\% of School Three's students qualified for free or reduced lunch. Teachers of Schools One and Two were given a one-hour training session on how to create interactive homework assignments. Children were pre-and-post tested to determine if interactive homework improved their ability to make inferences. A pre-parent-involvement survey was administered to ascertain the amount of time parents spent assisting their children with homework. During the 21-day study, parents were required to keep $\operatorname{logs}$ to record the amount of time devoted to their child's homework and to make comments about their own involvement.

The Bailey et al., 2004 study provided evidence that interactive homework did influence students' performance on reading inference tests and increased parental involvement. The results of the study matched the original hypothesis. The authors make the following suggestions to improve parental participation with homework. (1) Educators should consider making assignments designed to solicit parental interactions. (2) Educators should consider parents' and students' interests when making homework assignments. (3) Educators should make assignments that are appropriate 
for diverse populations to include not only multicultural diversity but other kinds of diversity as well, such as individual learning styles, interests, abilities, homework environments, etc. (4) Educators should consider effective delivery of assignments to students and parents, such as postings by e-mail or website or weekly newsletters, or students' notebooks. (5) Educators should make assignments that require students to use higher-order thinking skills. (6) Educators should make assignments that foster self-directedness and self-management skills (Bailey et al., 2004). Furthermore, the authors suggest that educators should involve parents in homework workshops that will provide parents with skills and motivation to engage in interactive homework with their children.

Machen, Wilson, and Notar (2005) discuss how parental involvement can influence student achievement and how to improve parental involvement, even in the upper grades.

This article uses information from published literature by Munoz, 2000, Adunyarittigun, 1997, and Pelco, Reis, Jacobson, and Melka, 2000. In the Pelco et al., 2000 study, ten fourth-and-sixth-grade students from various socioeconomic backgrounds were given the Burns/Roe Informal Reading Inventory for the purpose of measuring word recognition and comprehension skills. Measures showed poor aspects of reading ability and low motivation in the ten students. The Reader Self-Perception Scale (RSPS) was used to determine how students felt about themselves as readers. Parents were given a similar Likert scale questionnaire to determine parent's thoughts about their child as a reader. Complete results from the Pelco et al., 2000 questionnaires can found in Appendix D.

Recommendations for improving parent-school relations include the following. (1) Create frequent opportunities for positive communication with parents. (2) Reduce barriers that prevent parental involvement by providing babysitters and transportation to allow parents to attend school-related activities. (3) Schedule requested parent-teacher conferences during times that are favorable to the parents' schedule. (4) Arrange for parent-teacher conferences at locations other than the school which may be more convenient for the parents to meet. (5) Provide formal educational workshops for parents designed to increase the parents' ability to be more aware of their children's academic potential and aspirations (Machen, Wilson, and Notar, 2005).

\section{Conclusion}

Educators must use a variety of methods to obtain and sustain parental involvement. Schools must be proactive by explicitly inviting parents to be their partners. Local schools bear the responsibility of educating parents about the importance of parental involvement through workshops, newsletters, website information, brochures at school sporting events, and by every possible means.

Interactive homework (student notebooks, checklists, quick notes, and reminders) has powerful potential for promoting family-school partnerships which increase constructive learning outcomes. Using technology can help make home-school links more effective. Voice mail, e-mail, and websites make it possible for parents and students to get information about assignments, check current grades, keep informed about current class topics, as well as current school events, and schedule changes. Online communication offers opportunities for interacting with the teacher and gives parents the opportunity to stay connected with their child's education. As technology advances, and computers and Internet access become cheaper, many more homes will have computers making Internet the most effective link between home and school.

When parents and the educational system join together, positive benefits abound. Attendance, test scores, and high-school graduation rates improve. Teachers have higher expectations for parents and students and they develop more positive feelings about teaching. Extensive parental involvement promotes healthy neighborhoods and good schools.

\section{References}

Bailey, L. B., Silvern, S. B., Brabham, E., \& Ross, M. (2004). The effects of interactive reading homework andparent involvement on children's inference responses. [Electronic Version] Early Childhood Education Journal, 32(3), 173-178.

Bal, S. A., \& Goc, J. D. (1999). Increasing parent involvement to improve academic achievement in reading and math. Unpublished master's thesis, Saint Xavier University and IRI/Skylight, Chicago, Illinois. (ERIC Documents Reproduction Service No. ED438027)

Hoover-Dempsey, K. V., \& Sandler, H. M. (1995). Parental involvement in children's education: Why does it make a difference? [Electronic Version]. Teachers College Record, 92(2), 310-331.

Hoover-Dempsey, K. V., Battiato, A. C., Walker, J. M. T., Reed, R. P., DeJong, J. M., \& Jones, K. P. (2001). Parental involvement

in homework. [Electronic Version] Educational Psychologist, 36(3), 195-209. 
Machen, S. M., Wilson, J. D., \& Notar, C. E. (2005). Parental involvement in the classroom. [Electronic Version] Journal of Instructional Psychology. 32(1). 13-16.

Patterson, S. R. (1994). Increasing parental involvement in grades one, four, and five, in a rural elementary school. Unpublished

doctoral dissertation, Nova Southeastern University, Davie, FL. (ERIC Documentation Reproduction Service No. ED 389480)

Salend, S. J., Duhaney, D., Anderson, D. J., \& Gottschalk, C. (2004). Using the internet to improve homework communication

and completion.[Electronic Version] Teaching Exceptional Children. 36(3) 64-73.

Tobolka, D. (2006). Connecting teachers and parents through the internet. [Electronic Version] Tech Directions. 66(5). 24-26.

Van Voorhis, F. L.. (2003). Interactive homework in middle school: Effects on family involvement and science achievement. [Electronic Version] The Journal of Educational Research. 96(6). 323-338.

Walker, J. M., Hoover-Dempsey, K. V., Reed, R. P., \& Jones, K. P. (2000). Can you help me with my homework? Elementary school children's invitations and perspectives on parental involvement. Paper presented at the annual meeting of the American Educational Research Association, New Orleans, LA. (ERIC Documentation Reproduction Service No. ED443581) 


\section{Appendix A. Hoover-Dempsey \& Sandler (1995) Model}

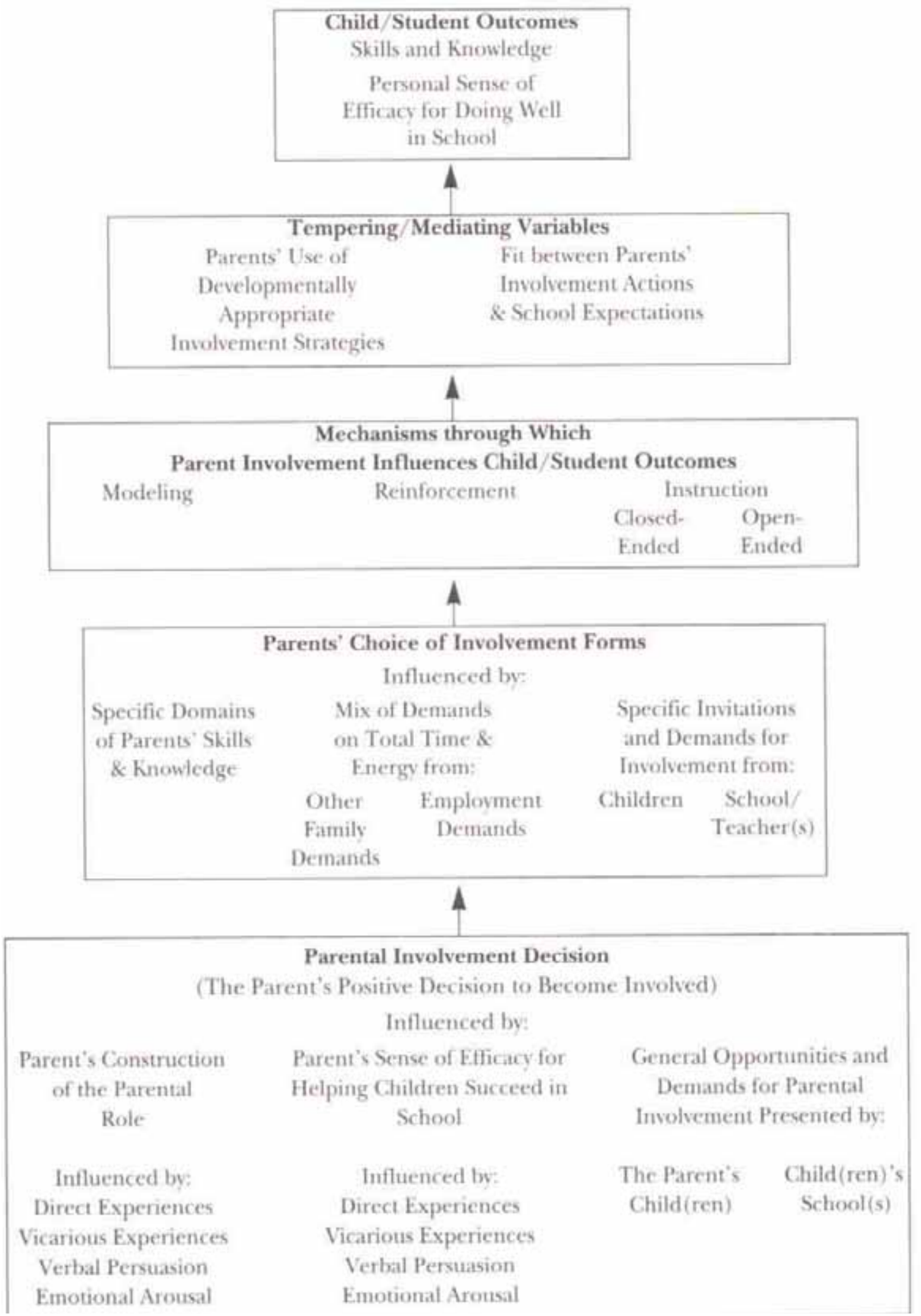


Appendix B. (Results from Bal and Goc Survey, 1999)

Parental communication/involvement within the school according to parents

\begin{tabular}{|l|l|l|l|l|}
\hline Survey item & \multicolumn{1}{|c|}{ Always } & \multicolumn{1}{|c|}{ Frequently } & \multicolumn{1}{|c|}{ Occasionally } & \multicolumn{1}{|c|}{ Pever } \\
\hline & Pre Post & Pre Post & PrePost & $4 \% 13 \%$ \\
\hline $\begin{array}{l}\text { Attend Open } \\
\text { House }\end{array}$ & $63 \% \quad 58 \%$ & $19 \% \quad 17 \%$ & $15 \% \quad 13 \%$ & $7 \% \quad 0 \%$ \\
\hline $\begin{array}{l}\text { Attend Parent } \\
\begin{array}{l}\text { Teacher } \\
\text { Conference }\end{array}\end{array}$ & $89 \% \quad 96 \%$ & $4 \% \quad 4 \%$ & $0 \% \quad 0 \%$ & $89 \% \quad 67 \%$ \\
\hline $\begin{array}{l}\text { Attend PTA } \\
\text { Meetings }\end{array}$ & $4 \% \quad 0 \%$ & $0 \% \quad 4 \%$ & $7 \% 17 \%$ & $22 \% 8 \%$ \\
\hline $\begin{array}{l}\text { Contact child's } \\
\text { teacher }\end{array}$ & $15 \% \quad 25 \%$ & $19 \% \quad 17 \%$ & $44 \% \quad 38 \%$ & $44 \% \quad 67 \%$ \\
\hline $\begin{array}{l}\text { Contact the } \\
\text { principal }\end{array}$ & $11 \% 4 \%$ & $7 \% 13 \%$ & $37 \% \quad 17 \%$ & \\
\hline
\end{tabular}

Parental academic involvement at home according to parents

\begin{tabular}{|c|c|c|c|c|}
\hline Survey Item & Always & Frequently & Occasionally & Never \\
\hline & Pre Post & Pre Post & Pre Post & Post \\
\hline $\begin{array}{l}\text { Go to the library } \\
\text { with your child }\end{array}$ & $7 \% \quad 20 \%$ & $37 \% 25 \%$ & $44 \% 46 \%$ & $11 \%$ \\
\hline $\begin{array}{l}\text { Read aloud to your } \\
\text { child }\end{array}$ & $15 \% 17 \%$ & $37 \% 38 \%$ & $26 \% 38 \%$ & $22 \% \quad 8 \%$ \\
\hline $\begin{array}{l}\text { Listen to your child } \\
\text { read }\end{array}$ & $37 \% 42 \%$ & $44 \% 42 \%$ & $15 \% 17 \%$ & $4 \% 0 \%$ \\
\hline $\begin{array}{l}\text { Discuss your child's } \\
\text { school day }\end{array}$ & $70 \% 79 \%$ & $19 \% 13 \%$ & $7 \% 8 \%$ & $4 \% 0 \%$ \\
\hline $\begin{array}{l}\text { Child seeks your } \\
\text { help with } \\
\text { schoolwork }\end{array}$ & $48 \% 42 \%$ & $41 \% 38 \%$ & $7 \% \quad 17 \%$ & $4 \% 4 \%$ \\
\hline $\begin{array}{l}\text { Help with homework } \\
\text { regularly }\end{array}$ & $48 \% 75 \%$ & $22 \% 13 \%$ & $11 \% 13 \%$ & $15 \% 19 \%$ \\
\hline $\begin{array}{l}\text { Study with your } \\
\text { child for tests }\end{array}$ & $67 \% 46 \%$ & $26 \% 33 \%$ & $4 \% \quad 17 \%$ & $4 \% 4 \%$ \\
\hline
\end{tabular}




\section{Appendix C. Parent/Guardian Survey}

Part A: Please check the answer that describes how often you are involved with the following.

\begin{tabular}{|c|c|c|c|c|}
\hline $\begin{array}{l}\text { Do you attend the } \\
\text { following: }\end{array}$ & Always & Frequently & Occasionally & Never \\
\hline Open House & & & & \\
\hline $\begin{array}{l}\text { Parent/Teacher } \\
\text { Conferences }\end{array}$ & & & & \\
\hline $\begin{array}{l}\text { School Plays/ } \\
\text { Sporting Events }\end{array}$ & & & & \\
\hline PTA Meetings & & & & \\
\hline $\begin{array}{l}\text { Do you contact your } \\
\text { child's teacher? }\end{array}$ & & & & \\
\hline $\begin{array}{l}\text { Do you contact the } \\
\text { Principal? }\end{array}$ & & & & \\
\hline $\begin{array}{l}\text { Do you volunteer to } \\
\text { help with class } \\
\text { activities? }\end{array}$ & & & & \\
\hline $\begin{array}{l}\text { Do you go to the library } \\
\text { with your child? }\end{array}$ & & & & \\
\hline $\begin{array}{l}\text { Do you purchase } \\
\text { educational materials to } \\
\text { assist your child with } \\
\text { school? }\end{array}$ & & & & \\
\hline $\begin{array}{l}\text { Do you read aloud to } \\
\text { your child? }\end{array}$ & & & & \\
\hline $\begin{array}{l}\text { Do you listen to your } \\
\text { child read? }\end{array}$ & & & & \\
\hline $\begin{array}{l}\text { Does your child seek } \\
\text { your help with } \\
\text { homework? }\end{array}$ & & & & \\
\hline $\begin{array}{l}\text { Do you offer assistance } \\
\text { to your child with } \\
\text { homework on a regular } \\
\text { basis? }\end{array}$ & & & & \\
\hline
\end{tabular}

1. What guidelines are enforced with your child regarding homework, watching television, play time, etc?

2. Please list the ways in which you are currently involved with your child's academic schooling?

3. What other ways would you like to become more involved with your child's schooling? 
Appendix D. (Results from Pelco et al., 2000 Study)

School Psychologists' Perspectives Regarding Family-School Partnership

\begin{tabular}{lccccc}
\hline & $\begin{array}{c}\text { Strongly } \\
\text { Disagree }\end{array}$ & Disagree & Agree & $\begin{array}{c}\text { Strongly } \\
\text { Agree }\end{array}$ & $\begin{array}{c}\text { Mean } \\
\text { Rating (SD) }\end{array}$ \\
\cline { 2 - 6 } & & & & & \\
$\begin{array}{l}\text { Parent involvement can help } \\
\text { increase student success in school. }\end{array}$ & $0.0 \%$ & $0.0 \%$ & $10.0 \%$ & $90.0 \%$ & $3.9(.3)$ \\
$\begin{array}{l}\text { Parents of children want } \\
\text { to be involved more than they } \\
\text { are now at most grade levels. }\end{array}$ & $1.4 \%$ & $29.3 \%$ & $59.0 \%$ & $10.3 \%$ & $2.8(.6)$ \\
$\begin{array}{l}\text { School psychologists do not } \\
\text { have time to help educators } \\
\text { involve families. }\end{array}$ & $17.2 \%$ & $42.3 \%$ & $30.9 \%$ & $9.6 \%$ & $2.3(.9)$ \\
$\begin{array}{l}\text { Mostly when I contact parents, } \\
\text { it's about academic or } \\
\text { behavior problems. }\end{array}$ & $1.7 \%$ & $11.1 \%$ & $58.5 \%$ & $28.7 \%$ & $3.1(.7)$ \\
$\begin{array}{l}\text { Every family has some strengths } \\
\text { that could be tapped to increase } \\
\text { student success in school. }\end{array}$ & $0.0 \%$ & $6.9 \%$ & $47.8 \%$ & $45.4 \%$ & $3.4(.6)$ \\
\hline
\end{tabular}

Sample $n=287$

Ratings were provided based on the following scale: $1=$ strongly disagree, $2=$ disagree, $3=$ agree, and $4=$ strongly agree. 